\title{
Melatonin and urological cancers: a new therapeutic approach
}

\author{
Mohammad Hossein Pourhanifeh ${ }^{1}$, Azam Hosseinzadeh², Kobra Bahrampour Juybari ${ }^{3}$ and Saeed Mehrzadi ${ }^{2^{*}}$ (])
}

\begin{abstract}
Urological cancers are responsible for thousands of cancer-related deaths around the world. Despite all developments in therapeutic approaches for cancer therapy, the absence of efficient treatments is a critical and vital problematic issue for physicians and researchers. Furthermore, routine medical therapies contribute to several undesirable adverse events for patients, reducing life quality and survival time. Therefore, many attempts are needed to explore potent alternative or complementary treatments for great outcomes. Melatonin has multiple beneficial potential effects, including anticancer properties. Melatonin in combination with chemoradiation therapy or even alone could suppress urological cancers through affecting essential cellular pathways. This review discusses current evidence reporting the beneficial effect of melatonin in urological malignancies, including prostate cancer, bladder cancer, and renal cancer.
\end{abstract}

Keywords: Bladder cancer, Prostate cancer, Renal cell carcinoma, Melatonin, Chemotherapy, Radiotherapy, Urological cancers, Angiogenesis, Apoptosis, Autophagy, Oxidative stress, Inflammation, metastasis

\section{Introduction}

Urological cancers, which account for $12 \%$ of malignancy-associated deaths across the world, mostly include cancers of the prostate, bladder and kidney. Prostate cancer is the most prevalent and accounts for one million new cases, and 300,000 deaths each year $[1,2]$. The second most frequent urological cancer is bladder cancer, which is the ninth most common cancer in the world. Annually, approximately 330,000 people are diagnosed with bladder cancer, which leads to about 130,000 deaths [2]. The main risk factors for bladder cancer are chronic irritation, environmental and chemical exposures (especially cigarette smoking), molecular aberrations (particularly $\mathrm{p} 21$ and Ras proteins and RB1, TP53, EGFR and TP63 genes), and 50-70 years of age [3]. Renal cell carcinoma (RCC) possesses the greatest mortality rates,

\footnotetext{
*Correspondence: Sa_mehrzadi@yahoo.com; mehrzadi.s@iums.ac.ir

${ }^{2}$ Razi Drug Research Center, Iran University of Medical Sciences, Tehran, Iran

Full list of author information is available at the end of the article
}

one-third of affected subjects. The main risk factors for RCC are hypertension, obesity, cigarette smoking, and age (50-70 years) [4]. Because of the resistance to treatment and metastasis, exploring novel therapeutic methods is vital for urological cancer therapy.

Melatonin is a molecule which has a broad spectrum of biological effects, including anti-angiogenic [5], anti-oxidant [6, 7], anti-inflammatory [8, 9], antinociceptive [10], weight-reducing, anti-obesogenic [11], anti-migration, anti-invasion [12-14], anticancer [15, 16], immunomodulatory [17], pro-apoptotic [18], and anti-proliferation activities [19]. Melatonin synchronizes circadian rhythms, and ameliorates the quality, duration and onset of sleep. Decline in the melatonin serum level, occurred during aging, various disease or artificial light exposure at night, leads to the disruption of cellular circadian rhythm; this is associated with the alterations in sleep-activity pattern, suppression of melatonin production, and deregulation of expression patterns of cancerrelated genes [20, 21]. Many clinical investigations have reported melatonin beneficial application in the therapy of cancers [22]. Melatonin suppresses tumor invasion

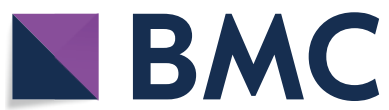

(c) The Author(s) 2020, corrected publication 2020. This article is licensed under a Creative Commons Attribution 4.0 International License, which permits use, sharing, adaptation, distribution and reproduction in any medium or format, as long as you give appropriate credit to the original author(s) and the source, provide a link to the Creative Commons licence, and indicate if changes were made. The images or other third party material in this article are included in the article's Creative Commons licence, unless indicated otherwise in a credit line to the material. If material is not included in the article's Creative Commons licence and your intended use is not permitted by statutory regulation or exceeds the permitted use, you will need to obtain permission directly from the copyright holder. To view a copy of this licence, visit http://creativecommons.org/licenses/by/4.0/. The Creative Commons Public Domain Dedication waiver (http://creativeco mmons.org/publicdomain/zero/1.0/) applies to the data made available in this article, unless otherwise stated in a credit line to the data. 
through inhibiting CCL24 via blocking the JNK pathway in osteosarcoma [13]. Melatonin represses colon cancer stem cells through modulating cellular prion protein/ Oct4 axis [23], and increases brain cancer stem cell sensitivity to paclitaxel [24]. In this review, we discuss available data of melatonin therapeutic effects in the treatment of urological cancers, based on molecular signaling pathways.

\section{Anticancer potentials of melatonin: mechanisms of actions}

Inhibitory impacts of melatonin on metastasis and growth of cancer cells have been widely studied. Of note, melatonin actions between healthy and tumoral cells are clearly different [12, 13, 25]; melatonin exerts its pro-apoptotic effects on cancer cells [26], but shows its anti-apoptotic properties in healthy cells [27]. This effect results from the differences of cancer cells with healthy cells in many ways including metabolism, gene regulation, and stress responses $[28,29]$. The ability of melatonin to scavenge free radicals has been proposed by several investigations [30]; however, a few in vitro studies have reported the stimulatory effect of melatonin on ROS production at pharmacological concentrations [28]. Melatonin suppresses tumor proliferation through inhibiting telomerase activity and cell cycle kinetics [12, 31]. Melatonin exerts angiostatic features through suppressing the expression and activation of vascular endothelial growth factor (VEGF) receptor 2 and inhibiting invasion, migration, and tube formation of endothelial cells [32]. Autophagy is another important mechanism implicated in controlling cellular homeostasis [33-35]. Autophagy possesses pro-survival actions; however, excessive autophagy probably results in cell fate, a process morphologically different from apoptosis [36]. Furthermore, autophagy-deficient malignant cells succumb to radiotherapy and chemotherapy, in vivo [37]. Melatonin mediates the generation of intracellular reactive oxygen species (ROS), whose accumulation has upstream roles in mitochondria-induced autophagy and apoptosis [38]. Melatonin impairs the apoptosis resistance and proliferation of cancer cells through inactivation of ROS-induced Akt signaling pathway; Akt stimulates the up-regulation of anti-apoptotic proteins including Bcl-2, PCNA and cyclin D1 and down-regulation apoptotic proteins such as Bax. Melatonin also inhibits the invasion and migration of cancer cells via inhibiting ROS-activated Akt signaling, leading to the Vimentin and Snail enhancement, and E-cadherin reduction [39]. Melatonin reduces proliferation and induces apoptosis in cancer cells through regulating PI3K/AKT/mTOR, Apaf-1/caspase-9, PI3K/ Akt, p300/nuclear factor kappa B (NF-kB) and COX-2/ PGE2 signaling pathways [40, 41]. Mitophagy removes injured mitochondria, which impairs chemotherapyinduced mitochondrial apoptosis. Melatonin is able to sensitize cancer cells to cisplatin-mediated apoptosis via suppression of JNK/Parkin/mitophagy pathway [42]. Importantly, melatonin modulates inflammatory and angiogenic proteins which are responsible for tumor progression [43]. The nuclear translocation of NF- $\mathrm{kB}$ and the expression of pro-inflammatory factors, such as tumor necrosis factor- $\alpha$ (TNF- $\alpha$ ), interleukin- $1 \beta$ (IL-1 $\beta)$, and IL- 6 are reduced by melatonin [44]. Furthermore, melatonin reverses chemotherapy resistance through repressing the $\mathrm{Wnt} / \beta$-catenin pathway and controls migration and invasion of cancer stem cells $[45,46]$. Results from clinical studies indicate that melatonin improves the sleep and quality of life in patients with cancer. Furthermore, combination of melatonin with anticancer drugs enhances the therapeutic effect of chemotherapeutic agents and survival of patients with cancer [47, 48]. Melatonin is suggested to overcome drug resistance through (I) increasing response to chemotherapeutics agents via modulation of the expression and phosphorylation of their targets, (II) reducing the clearance of chemotherapeutics by impressing their metabolism and transport, (III) decreasing the survival of malignant cells via alteration of DNA and (IV) regulating cell death-associated mechanisms such as apoptosis and autophagy [49]. Regarding what briefly discussed above, anticancer effects of melatonin widely investigated during last decades. Herein, the therapeutic actions of melatonin have been evaluated on the pathogenesis of urological cancers.

\section{Therapeutic application of melatonin and urological cancers: focus on signaling pathways therapeutic application of melatonin and urological cancers: focus on signaling pathways}

\section{Prostate cancer}

The incidence of prostate cancer significantly elevates among males by increasing age. A systematic review of epidemiologic studies has reported an association between circadian disruption or sleep loss and prostate cancer [50]. A prospective association between first morning-void urinary 6-sulfatoxymelatonin (aMT6s) level and risk for prostate cancer has been reported by a case-cohort study; men with morning urinary aMT6s level below the median possess a fourfold higher risk for advanced or lethal prostate cancer compared to men with higher level [51]. Examination of circadian rhythms of melatonin showed that the level of melatonin reduces in the serum of patients with primary prostate cancer; this depression of serum melatonin has been reported to be due to a reduced pineal activity and be not caused by an enhanced metabolic degradation in the liver [52]. 
Melatonin increases the survival of animals by $33 \%$ when administered at the beginning or at advanced tumor stages [53]. Melatonin controls and represses this type of cancer by induction of apoptosis through regulating the generation of ROS, mitochondrial bioenergetics and several signaling pathways, including JNK and p38 pathways $[54,55]$.(. Melatonin considerably inhibits the expression and activity of Sirt1 protein in prostate cancer cells, which this is accompanied by a remarkable reduction in the proliferative activity of cancer cells. Prostate cancer cells are protected from anti-proliferative effects of melatonin by forced Sirt1 overexpression, proposing that Sirt1 may be a direct melatonin target [56]. The beneficial effects of melatonin in declining tumor growth are related to the reduction of angiogenesis [57]; to suppress tumor angiogenesis, melatonin inhibits the activity of hypoxia-inducible factor (HIF)- $1 \alpha$ resulting in the inhibition of its target genes expressions in prostate cancer cells [58]. Up-regulation of miRNA-374b and miRNA3195 by melatonin results in the attenuation of HIF-1/2 $\alpha$ and VEGF expression [59]. Tai and colleagues selected 120 newly diagnosed prostate cancer subjects as well as 240 age-matched controls and measured their main urine metabolites. Individuals having a high melatonin-sulfate/ cortisol (MT/C) ratio or high levels of melatonin-sulfate were less probable to possess prostate cancer or malignancy in advanced stages [60].

Melatonin exerts anti-androgenic effects on prostate cells through blocking androgen receptor nuclear translocation and disrupting the positive interaction between androgen receptor splice variant-7 (AR-V7) expression and activated NF- $\mathrm{\kappa B} / \mathrm{IL}-6$ signaling $[53,61]$. This anti-androgenic effect of melatonin is mediated by the activation of MT1 receptor leading to the delay in the development of castration resistance in advanced prostate cancer [61]. Melatonin promotes cell toxicity and death caused by cytokines including TNF- $\alpha$ and TNF-related apoptosis-inducing ligand (TRAIL) without affecting the action of chemotherapeutic agents [62]. Terraneo et al. investigated the effect of melatonin on prostate cancer cells when delivered by cryopasslaser or intraperitoneal administration. Intraperitoneal administration of melatonin has been reported to be as effective as cryopass-laser therapy in attenuating prostate cancer cell growth, and influencing redox balance and melatonin plasma level. The effect of cryopass-laser is less than intraperitoneal delivery route of melatonin in enhancing Nrf2 expression and melatonin content in tumor mass. However, cryopass-laser treatment of melatonin is as effective as its intraperitoneal administration in the inhibition of HIF- $1 \alpha$. Overall, cryopass-laser therapy could be an effective method to transdermal delivery of melatonin to the site of action without causing pain [63]. To prove melatonin effectiveness in prostate cancer therapy, further studies are needed. Table 1; Fig. 1 summarize present information of melatonin therapy for prostate cancer.

\section{Bladder cancer}

Radical cystectomy is known as the standard therapy for bladder cancer with neoadjuvant chemotherapy [64]; however, 5-year survival of subjects with metastatic form of this cancer is still low [65, 66]. Although various therapeutic approaches have been developed up to now, bladder cancer mortality rate has not significantly ameliorated. Therefore, finding novel effective therapies are required. As discussed in detail, melatonin deserves to be chosen at least as an adjuvant for the therapy of diverse cancers. Few but valuable studies have investigated the effect of melatonin on bladder cancer. Therefore, we summarize them here and in Table 2; Fig. 2.

Synergistic anticancer effects of melatonin in combination with curcumin have been evaluated against bladder cancer [67]; this combination results in a promoted suppression of bladder cancer cell proliferation. Moreover, melatonin and curcumin combination blocks the activity of ІкB kinase $\beta$ (IKK $\beta$ ), leading to the repression of NF- $\mathrm{kB}$ nuclear translocation and their binding on COX-2 promoter. This combination mediates apoptosis in bladder cancer cells via increasing cytochrome c release into the cytosol. Therefore, melatonin synergizes curcumin suppressive impacts against bladder cancer growth through promoting the proapoptotic, anti-migration, and anti-proliferation functions. This indicates that this combination might reveal efficient therapeutic potential in the therapy of bladder cancer. Melatonin induces cell cycle arrest at G0 phase and inhibits colony formation, mitochondrial membrane potential, cell migration, and the growth of bladder cancer cells. Melatonin also blocks oxidative stress, and inhibits AKT-MMP9 signaling pathway leading to the reduction of invasion, migration, and growth of bladder cancer cells [68].

Combination of valproic acid and melatonin stimulates the expression of particular genes involved in necrosis (RIPK1, PARP-1, and MLKL), autophagy (ATG5, ATG3, and BECN) and apoptosis (such as TNFRSF10B and TNFRSF10A). This combination activates Raf/MEK/ ERK and Wnt signaling pathways, up-regulates expressions of E-cadherin and endoplasmic reticulum-stressrelated genes including ERdj4, EDEM1, IRE1, and ATF6 and down-regulates expressions of Slug, Snail, Fibronectin, and $N$-cadherin. These suggest that combination 
Table 1 Investigations on melatonin treatment against prostate cancer

\begin{tabular}{|c|c|c|c|c|c|}
\hline $\begin{array}{l}\text { Melatonin dose } \\
\text { or concentration }\end{array}$ & Targets & Effects & Model & Cell line & Refs \\
\hline $1 \mathrm{pM}, 1 \mathrm{nM}, 1 \mu \mathrm{M}, 1 \mathrm{mM}$ & $\begin{array}{l}\text { mTOR, ERK1/2, Akt, OXPHOS, } \\
\text { ROS }\end{array}$ & $\begin{array}{l}\text { Anti-proliferative and antioxi- } \\
\text { dant effects }\end{array}$ & In vitro & PNT1A & {$[55]$} \\
\hline UCM 1037 (analogue) & Androgen receptor, Akt & $\begin{array}{l}\text { Anti-proliferative and cytotoxic } \\
\text { effects against cancer cells }\end{array}$ & In vitro & LNCaP, PC3, DU145, 22Rv1 & {$[76]$} \\
\hline $1 \mathrm{mM}$ & Pentose phosphate pathway & $\begin{array}{l}\text { Decreased LDH activity, tricar- } \\
\text { boxylic acid cycle, ATP/AMP } \\
\text { ratio, glucose uptake, and } \\
\text { lactate labeling } \\
\text { Limited glycolysis }\end{array}$ & In vitro & LNCaP, PC-3 & {$[77]$} \\
\hline $3 \mathrm{mg} / \mathrm{kg}$ & $\mathrm{Nrf2}, \mathrm{HIF}-1 \mathrm{a}$ & Inhibited tumor growth & In vivo & LNCaP & {$[63]$} \\
\hline $10^{-6} \mathrm{M}$ & NF-kB, AR-V7, IL-6, & $\begin{array}{l}\text { Delayed castration resistance } \\
\text { development }\end{array}$ & In vitro & LNCaP, 22Rv1 & [61] \\
\hline $\begin{array}{l}200 \mu \mathrm{g} / \mathrm{ml} \\
50 \mu \mathrm{M}-1 \mathrm{mM}\end{array}$ & MAPK/ERK, IGFBP3 & $\begin{array}{l}\text { Increased survival time of } \\
\text { TRAMP mice when admin- } \\
\text { istered at the initiation or } \\
\text { advanced stages }\end{array}$ & In vivo, in vitro & LNCaP & [53] \\
\hline $\begin{array}{l}10 \mu \mathrm{g} / \mathrm{kg} \\
500 \mu \mathrm{M}, 5 \mathrm{mM}, 10 \mathrm{mM}\end{array}$ & $\begin{array}{l}\text { Androgen receptor (AR), PCNA, } \\
\text { MTR1B }\end{array}$ & $\begin{array}{l}\text { proliferative and anti-apoptotic } \\
\text { effects in prostate cells } \\
\text { subjected to HG levels }\end{array}$ & In vivo, in vitro & PNTA1, PC-3 & [78] \\
\hline $1 \mathrm{mM}$ & $\begin{array}{l}\text { VEGF, HIF-1a, HIF-2a, miR-3195, } \\
\text { miR-374b }\end{array}$ & Anti-angiogenic activity & In vitro & $P C-3$ & [59] \\
\hline $1 \mathrm{mg} / \mathrm{kg}$ & Nrf2, Ki67, HIF-1a, Akt & $\begin{array}{l}\text { Inhibited cancer growth and } \\
\text { exerted anti-angiogenic } \\
\text { effects }\end{array}$ & In vivo & LNCaP & {$[57]$} \\
\hline $10^{-8} \mathrm{M}$ & p27, NF-kB, MT1, & Anti-proliferative effects & In vitro & LNCaP, 22Rv1 & {$[79]$} \\
\hline $1 \mathrm{mM}$ & TRAIL, TNF- $a$ & $\begin{array}{l}\text { Promotes cell toxicity and can- } \\
\text { cer cell death, inhibited oxi- } \\
\text { dative stress, and suppressed } \\
\text { cancer cell proliferation }\end{array}$ & In vitro & LNCaP, PC-3 & {$[62]$} \\
\hline $10 \mathrm{mg} / \mathrm{kg}$ & $\mathrm{GSH}, \mathrm{MDA}, \mathrm{SOD}$ & $\begin{array}{l}\text { Inhibited tumor growth and } \\
\text { oxidative stress }\end{array}$ & In vivo & - & {$[80]$} \\
\hline $10^{-11}-10^{-5} \mathrm{M}$ & MT1, p27, AR & Anti-proliferative effects & In vitro & RWPE-1, 22Rv1, VCaP, LNCaP & {$[81]$} \\
\hline $1 \mathrm{mM}$ & $\begin{array}{c}\text { Akt/GSK-3ß, HIF-1a, SPHK1, } \\
\text { VEGF, von Hippel-Lindau }\end{array}$ & Antioxidant effects & In vitro & $P C-3$ & {$[82]$} \\
\hline $100 \mathrm{nM}-2 \mathrm{mM}$ & $\begin{array}{l}\text { Sirt1, IGF-1)/IGFBP3, PCNA, } \\
\text { Ki-67 }\end{array}$ & $\begin{array}{l}\text { Anti-proliferative effects } \\
\text { Inhibited tumorigenesis }\end{array}$ & In vivo, in vitro & PC-3, DU145, 22Rv1, LNCaP & {$[56]$} \\
\hline $100 \mu \mathrm{M}, 1 \mathrm{mM}, 2 \mathrm{mM}$ & Per2, Clock, Bmal1 & $\begin{array}{l}\text { Anti-proliferative effects } \\
\text { Caused a resynchronization of } \\
\text { oscillatory circadian rhythm } \\
\text { genes }\end{array}$ & In vitro & PC-3, DU145, 22Rv1, LNCaP & {$[83]$} \\
\hline $10^{-8}-10^{-3} \mathrm{M}$ & - & $\begin{array}{l}\text { Inhibited viability and induced } \\
\text { apoptosis }\end{array}$ & In vitro & PC-3, DU145, 22Rv1, LNCaP & {$[84]$} \\
\hline $1 \mathrm{mM}$ & HIF-1a, & Anti-angiogenic effect & In vitro & PC-3, DU145, LNCaP & [58] \\
\hline $0-3 \mathrm{mM}$ & p38, JNK & $\begin{array}{l}\text { Induced apoptosis } \\
\text { Inhibited cancer cell growth }\end{array}$ & In vitro & LNCaP & {$[54]$} \\
\hline $10^{-9}, 10^{-8}, 10^{-7}$ & PKA, PKC, p27, MT1 & Anti-proliferative effects & In vitro & 22Rv1 & [85] \\
\hline $10^{-11}, 10^{-5}$ & $\begin{array}{l}\text { p27, PKA, PKC, MT1, andro- } \\
\text { gen signaling }\end{array}$ & Anti-proliferative effects & In vitro & 22Rv1 & {$[86]$} \\
\hline $0.5,1 \mathrm{mM}$ & - & $\begin{array}{l}\text { Induced cell cycle arrest and } \\
\text { cellular differentiation } \\
\text { Inhibited proliferation of } \\
\text { cancer cells }\end{array}$ & In vitro & LNCaP, PC-3, & {$[87]$} \\
\hline $5 \mathrm{mg}$ & MT1 & $\begin{array}{l}\text { Anti-proliferative effects } \\
\text { Induced stabilization of } \\
\text { patient's hormone-refractory } \\
\text { disease }\end{array}$ & Human & - & {$[88]$} \\
\hline
\end{tabular}


Table 1 (continued)

\begin{tabular}{|c|c|c|c|c|c|}
\hline $\begin{array}{l}\text { Melatonin dose } \\
\text { or concentration }\end{array}$ & Targets & Effects & Model & Cell line & Refs \\
\hline $4 \mu \mathrm{g} / \mathrm{g}$ & EGF, Cyclin D1 & $\begin{array}{l}\text { Inhibited tumor growth and } \\
\text { proliferation }\end{array}$ & In vivo & PC-3, DU145, LNCaP & {$[89]$} \\
\hline- & - & $\begin{array}{l}\text { AR activity attenuation } \\
\text { by melatonin is not due to } \\
\text { inhibition of AR binding to } \\
\text { the androgen responsive } \\
\text { element (ARE) }\end{array}$ & In vitro & LNCaP, PC-3 & {$[90]$} \\
\hline $4 \mu \mathrm{g} / \mathrm{g}$ & MT1 & Anti-proliferative effects & In vivo & PC-3, LNCaP & {$[91]$} \\
\hline $0.01-100 \mathrm{nM}$ & CAMP & $\begin{array}{l}\text { suppressed cancer cell pro- } \\
\text { liferation and induced cell } \\
\text { cycle arrest }\end{array}$ & In vitro & DU145 & {$[92]$} \\
\hline $5 \times 10^{-11}-5 \times 10^{-5}$ & $\begin{array}{l}\text { MT1, sex steroid-mediated } \\
\text { calcium influx }\end{array}$ & Anti-proliferative effects & In vitro & LNCaP & [93] \\
\hline $0.01-1000 \mathrm{nM}$ & Mel1a receptor & Anti-proliferative effects & In vitro & LNCaP & {$[94]$} \\
\hline $20 \mathrm{mg}$ & IGF-1, PRL & $\begin{array}{l}\text { Combination therapy with } \\
\text { triptorelin and melatonin } \\
\text { decreased PSA mean con- } \\
\text { centrations } \\
\text { Melatonin reversed clinical } \\
\text { resistance to LHRH analogue } \\
\text { triptorelin in metastatic } \\
\text { prostate cancer }\end{array}$ & Human & - & {$[95]$} \\
\hline $50 \mu \mathrm{g}$ & - & Inhibited tumor growth & In vivo & Dunning R-3327-HIF tumor & {$[96]$} \\
\hline
\end{tabular}

of valproic acid and melatonin increases cytotoxicity through modulating cell death pathways in bladder cancer [69].

\section{Kidney cancer}

Kidney cancer is responsible for $2-3 \%$ of all cancers, and RCC is the most common type of this cancer. Among urological malignancies, RCC is believed to be the most lethal [70]. The 5-year survival rate of RCC is approximately 93\%; however, this rate for patients with metastatic RCC is $12 \%$ [71]. Similar to other urological cancers, searching for appropriate therapy for the treatment of this malignancy is essential. Melatonin is believed to possess the potential to suppress this cancer.

Melatonin suppresses RCC metastasis by suppressing Akt-MAPKs pathway, DNA-binding activity of NF-kB and MMP-9 transactivation [72]. Combination of melatonin and thapsigargin induces apoptosis in renal cancer cells through up-regulating CCAAT-enhancer-binding proteins homologous protein ( $\mathrm{CHOP}$ ) expression; the up-regulation of $\mathrm{CHOP}$ expression is melatonin receptorindependent and may result from antioxidant properties of melatonin [73]. Furthermore, Kahweol and melatonin combination up-regulates the p53-upregulated modulator of apoptosis (PUMA) through endoplasmic reticulum stress-induced $\mathrm{CHOP}$ induction and p53-independent pathway [74]. Melatonin could induce apoptosis in renal cancer cells through up-regulating the expression of E2F1 and Sp1, leading to the enhancement of the expression of Bcl-2-interacting mediator of cell death (Bim). Melatonin also modulates the stability of Bim protein via inhibiting proteasome activities. However, up-regulation of Bim induced by melatonin is independent of melatonin receptors and antioxidant potentials. Overall, these findings show that melatonin mediates apoptosis by up-regulating the expression of Bim at transcriptional levels and at the post-translational levels [75]. Table 3; Fig. 3 illustrates a summary of carried out investigations related to melatonin therapeutic roles in renal cancer therapy.

\section{Conclusion}

Urological cancers are serious life-threatening diseases for societies and account for thousands of morbidity and mortality each year. Because standard therapies have not been able to increase survival time in affected patients, researchers should make so many attempts to produce further efficient drugs as alternative, complementary or adjuvant for cancer therapy. In addition to the improvement of sleep and quality of life in patients with cancer, melatonin in combination with anticancer agents increases the efficacy of routine medicine and survival rate of patients with cancer. The present review 


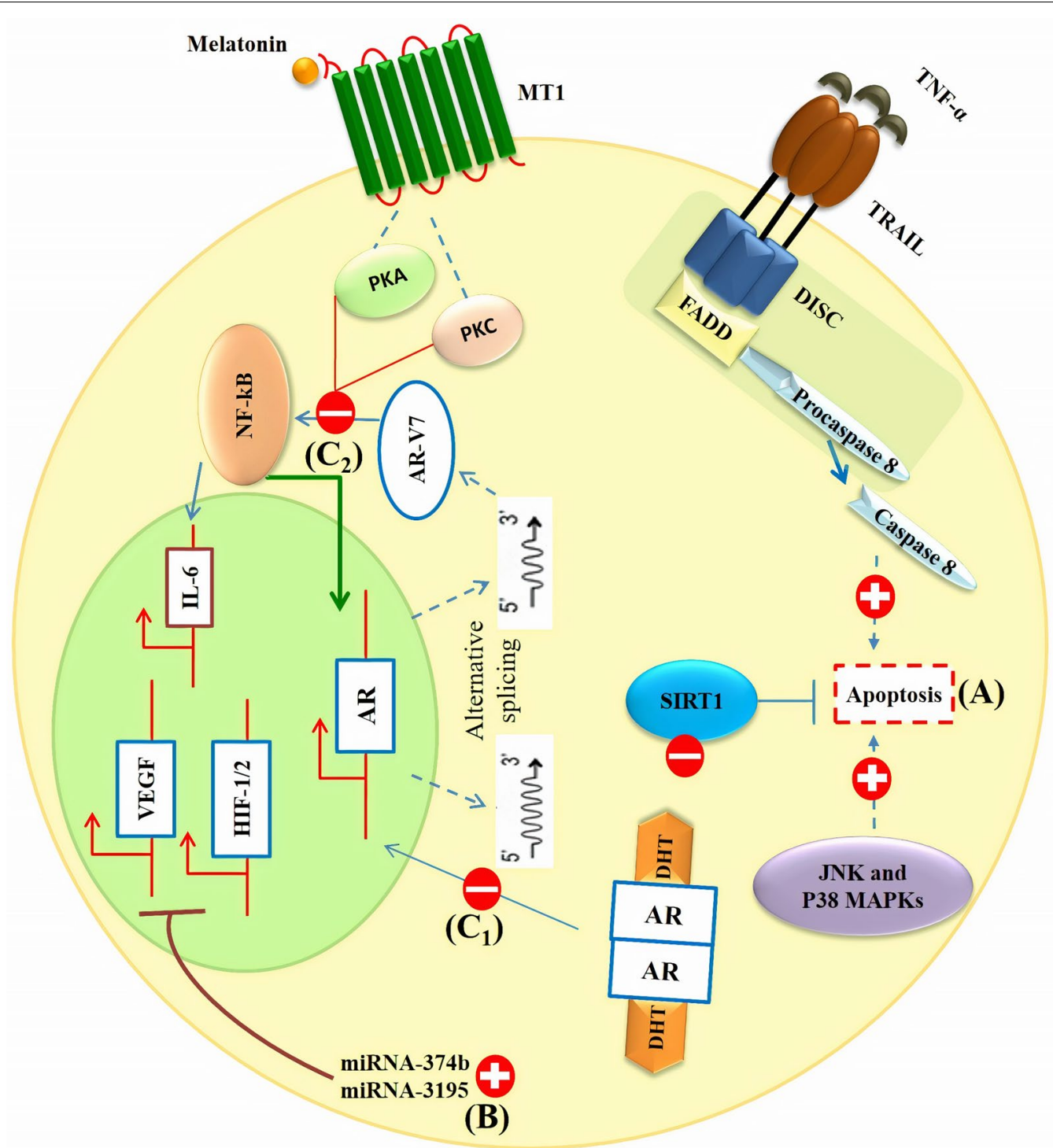

Fig. 1 Melatonin (a) promotes apoptosis in prostate cancer cells through activating TNF-a/TRAIL, JNK and P38 signaling pathways, and inhibiting SIRT1 pathway, (b) inhibits angiogenesis by inhibition of HIF-1/2a and VEGF expression and $\left(\mathbf{C}_{1}\right)$ exerts anti-androgenic effects by inhibiting nuclear translocation of androgen receptor and $\left(\mathbf{C}_{2}\right)$ MT1 receptor-dependent disruption of positive interaction between androgen receptor splice variant-7 (AR-V7) expression and NF-KB/IL-6 signaling

Table 2 Results from experimental studies of melatonin application against bladder cancer

\begin{tabular}{|c|c|c|c|c|c|}
\hline $\begin{array}{l}\text { Melatonin dose } \\
\text { or concentration }\end{array}$ & Targets & Effects & Model & Cell line & Refs \\
\hline $\begin{array}{l}10 \mathrm{mg} / \mathrm{kg} \\
1 \mathrm{mM}\end{array}$ & $\begin{array}{l}\text { cytochrome c, NF-KB, } \\
\text { COX-2, IKK }\end{array}$ & $\begin{array}{l}\text { Combination of melatonin and curcumin induced cell } \\
\text { apoptosis } \\
\text { Melatonin exerted pro-apoptotic, anti-migration, and anti- } \\
\text { proliferative functions } \\
\text { Melatonin synergized curcumin ability to suppress tumor } \\
\text { growth }\end{array}$ & $\begin{array}{l}\text { In vivo, } \\
\text { in vitro }\end{array}$ & $\begin{array}{l}\text { 5637, UMUC3, } \\
\text { T24 }\end{array}$ & {$[67]$} \\
\hline 100 mg/kg & $\begin{array}{l}\text { ZNF746, p-AKT/MMP-2/ } \\
\text { MMP-9 }\end{array}$ & $\begin{array}{l}\text { Inhibited cancer cell growth, invasion, and migration } \\
\text { Induced cell cycle arrest } \\
\text { Suppressed oxidative stress }\end{array}$ & $\begin{array}{l}\text { In vivo, } \\
\text { in vitro }\end{array}$ & $\begin{array}{l}\text { HT1376, HT1197, } \\
\text { RT4, T24 }\end{array}$ & [68] \\
\hline $10^{-6} \mathrm{M}$ & $\begin{array}{l}\text { Wht, E-cadherin, N-cad- } \\
\text { herin Raf/MEK/ERK }\end{array}$ & $\begin{array}{l}\text { Combination of valproic acid and melatonin enhanced cyto- } \\
\text { toxicity by modulating cell death pathways }\end{array}$ & In vitro & UC3 & [69] \\
\hline
\end{tabular}


Apoptotic related genes and proteins:

Bax/Bcl2, Caspase 3, Cytochrome c,

TNFRSF10A, TNFRSF10B, Ras/MEK/ERK

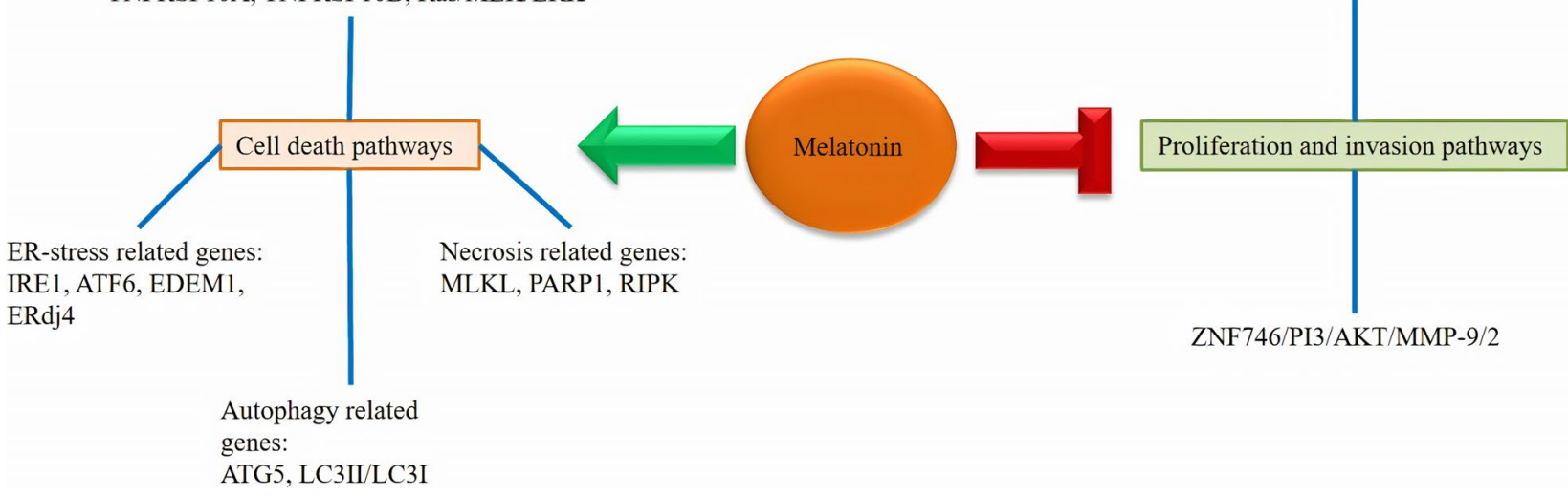

Fig. 2 Melatonin affects some signaling pathways leading to the induction of cell death and inhibition of invasion and proliferation of bladder cancer cells

Table 3 A summary of current findings of melatonin for renal cancer treatment

\begin{tabular}{|c|c|c|c|c|c|}
\hline $\begin{array}{l}\text { Melatonin dose } \\
\text { or concentration }\end{array}$ & Targets & Effects & Model & Cell line & Refs \\
\hline $\begin{array}{l}200 \mathrm{mg} / \mathrm{kg} \\
0.5,1,2 \mu \mathrm{mol} / \mathrm{L}\end{array}$ & PGC1A, UCP1 & $\begin{array}{l}\text { Eliminated the abnormal lipid deposits } \\
\text { Repressed tumor progression } \\
\text { Induced autophagy }\end{array}$ & In vivo & HK2, 786-O, A498, Caki-1, ACHN & {$[97]$} \\
\hline $0.5-2 \mathrm{mM}$ & MMP-9, JNK1/2, ERK1/2, MT1 & Suppressed metastasis and invasion & In vitro & Caki-1, Achn & {$[72]$} \\
\hline $0.1,0.5$, or $1 \mathrm{mM}$ & Bim, E2F1, Sp1, proteasome & Induced apoptosis & In vitro & A549, HT29, Caki & {$[75]$} \\
\hline $\begin{array}{l}20 \mathrm{mg} / \mathrm{kg} \\
10 \mu \mathrm{M}\end{array}$ & HIF-1a & $\begin{array}{l}\text { Inhibits tumor growth and blocks tumor } \\
\text { angiogenesis }\end{array}$ & In vivo, in vitro & RENCA & [98] \\
\hline $1 \mathrm{mM}$ & $\mathrm{CHOP}$ & Induced apoptosis & In vitro & HCT116, HT29, Caki & {$[73]$} \\
\hline $1 \mathrm{mM}$ & PUMA & Induced apoptosis & In vitro & Caki & {$[74]$} \\
\hline $1 \mathrm{mM}$ & Mcl-1 & Attenuated oxaliplatin-mediated apoptosis & In vitro & Caki & [99] \\
\hline $20 \mathrm{mg}$ & - & $\begin{array}{l}\text { Increased survival } \\
\text { Abrogated the negative influences of opi- } \\
\text { oids on IL-2 immunotherapy cancer cells }\end{array}$ & Human & - & {$[100]$} \\
\hline $40 \mathrm{mg}$ & - & $\begin{array}{l}\text { Combination of immunotherapy with IL-2 } \\
\text { plus melatonin increased survival time, } \\
\text { and lymphocyte and eosinophil number }\end{array}$ & Human & - & [101] \\
\hline $10 \mathrm{mg}$ & - & $\begin{array}{l}\text { In addition to anticancer effects, low doses } \\
\text { of human lymphoblastoid } \\
\text { interferon and melatonin showed no toxic- } \\
\text { ity in patients }\end{array}$ & Human & - & [102] \\
\hline
\end{tabular}

suggests that melatonin can be utilized as adjuvant of cancer therapies through reducing possible adverse events of chemotherapy or radiotherapy and increasing the sensitivity of cancer cells to medical treatments. The underlying mechanisms mainly include inhibition of cell survival, metastasis, angiogenesis, and clone formation. Furthermore, melatonin reduces resistance to treatment in cancers through the modulation of the expression and phosphorylation of drug targets, the reduction of the clearance of chemotherapeutics, the alteration of DNA of malignant cells and the regulation of cell death-associated mechanisms such as apoptosis and autophagy. Notably, it is obvious that multiple 


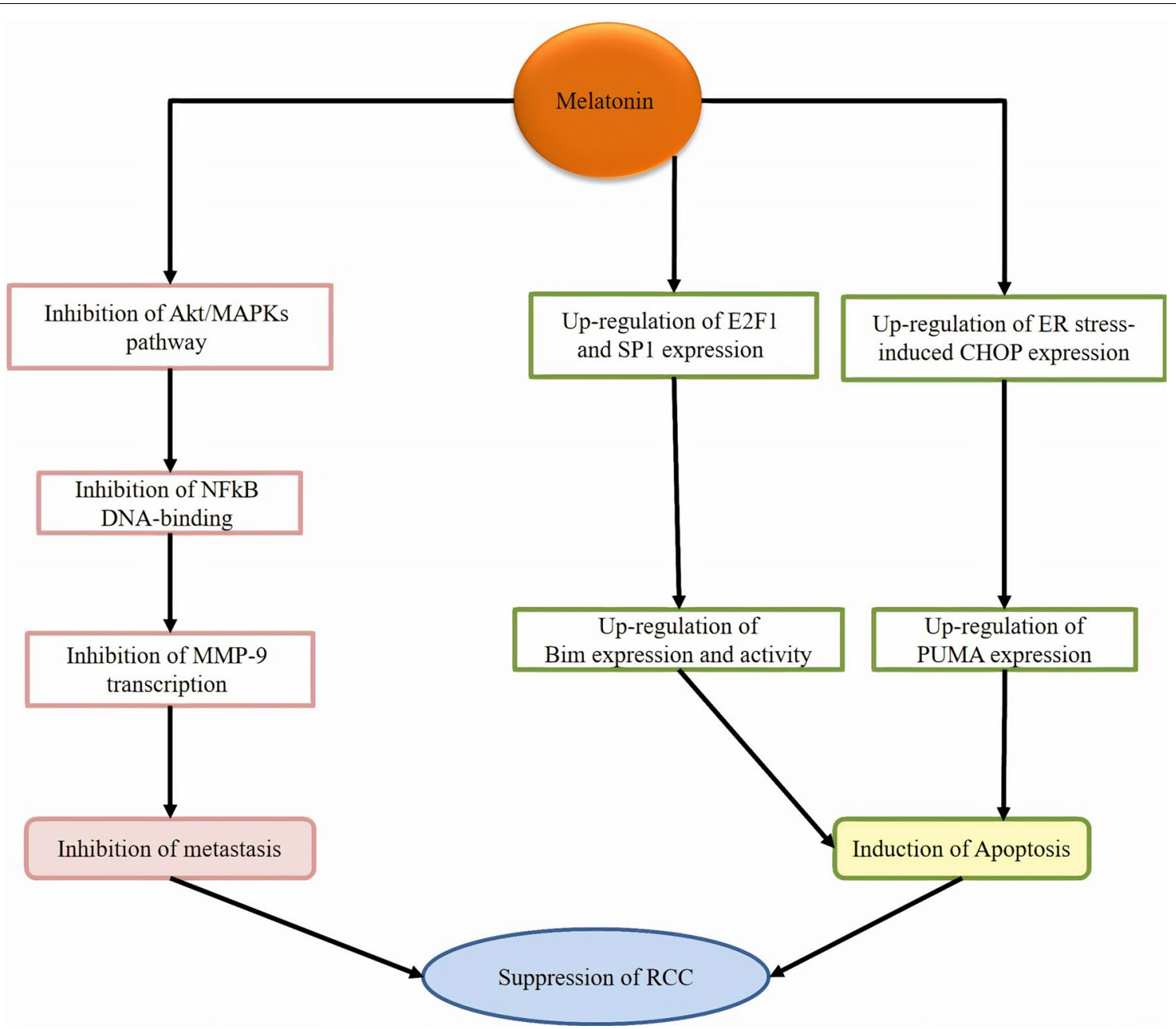

Fig. 3 Melatonin suppresses RCC through affecting signaling molecules involved in metastasis and apoptosis

studies should be conducted, particularly human trials, to prove its safety and effectiveness in patients with different malignancies, including urological cancers.

\section{Abbreviations}

RCC: Renal cell carcinoma; CCL24: C-C motif chemokine ligand 24; JNK: C-Jun $\mathrm{N}$-terminal kinase; Oct4: Octamer-binding transcription factor 4; ROS: Reactive oxygen species; VEGF: Vascular endothelial growth factor; TNF-a: Tumor necrosis factor-a; IL-1 B: Interleukin-1 $\beta$; IL-6: Interleukin-6; Nrf2: Nuclear factor erythroid 2-related factor 2; Apaf-1: Apoptotic protease activating factor-1; COX-2: Cyclooxygenase-2; PGE2: Prostaglandin E2; Sirt1: Sirtuin; PC-3 cells: Human prostate cancer cells; HIF: Hypoxia-inducible factor; MT/C: Melatoninsulfate/cortisol; TRAIL: TNF-related apoptosis-inducing ligand; IKKß: IkB kinase B; MMP9: Matrix metallopeptidase 9; RIPK1: Receptor-interacting serine/threonine-protein kinase 1; PARP-1: Poly [ADP-ribose] polymerase 1; MLKL: Mixed lineage kinase domain like pseudokinase; ATG: Autophagy related; ERdj4: Endoplasmic reticulum localized DnaJ 4; EDEM1: Endoplasmic reticulum degradation enhancing alpha-mannosidase like protein 1; IRE1: Inositol-requiring enzyme 1; ATF6: Activating transcription factor 6; ERK: Extracellular signalregulated kinase; Raf: Raf-1 proto-oncogene, serine/threonine kinase; MEK: Mitogen-activated protein kinase kinase; MAPK: Mitogen-activated protein kinase; CHOP: CCAAT-enhancer-binding proteins homologous protein; PUMA: p53-upregulated modulator of apoptosis; GSH: Glutathione; Sp1: Specificity protein 1; Bim: Bcl-2-interacting mediator of cell death; PI3K: Phosphatidylinositol-3-kinase; Akt: Protein kinase B.

\section{Acknowledgements}

This research did not receive any specific grant from funding agencies in the public, commercial, or not for-profit sectors.

\section{Authors' contributions}

Conception and design: SM and MHP. Performing the literature search: KBJ and AH. Drafting the manuscript: all authors. Approving the final version: all authors. SM is responsible for the integrity of the work as a whole. All authors read and approved the final manuscript.

\section{Funding}

This research did not receive any specific grant from funding agencies in the public, commercial, or not for-profit sectors.

\section{Availability of data and materials}

Not applicable.

\section{Ethics approval and consent to participate}

Not applicable.

\section{Consent for publication}

Not applicable. 


\section{Competing interests}

The authors declare that they have no competing interests.

\section{Author details}

${ }^{1}$ Research Center for Biochemistry and Nutrition in Metabolic Diseases, Kashan University of Medical Sciences, Kashan, Iran. ${ }^{2}$ Razi Drug Research Center, Iran University of Medical Sciences, Tehran, Iran. ${ }^{3}$ Department of Pharmacology, School of Medicine, Semnan University of Medical Sciences, Semnan, Iran.

Received: 29 April 2020 Accepted: 1 September 2020

Published online: 10 September 2020

\section{References}

1. Center MM, Jemal A, Lortet-Tieulent J, Ward E, Ferlay J, Brawley O, Bray F. International variation in prostate cancer incidence and mortality rates. Eur Urol. 2012;61(6):1079-92.

2. Ferlay J, Shin HR, Bray F, Forman D, Mathers C, Parkin DM. Estimates of worldwide burden of cancer in 2008: GLOBOCAN 2008. Int J Cancer. 2010;127(12):2893-917.

3. Kaufman DS, Shipley WU, Feldman AS. Bladder cancer. Lancet. 2009:374(9685):239-49.

4. Cohen HT, McGovern FJ. Renal-cell carcinoma. N Engl J Med. 2005;353(23):2477-90

5. Mansoor S, Saeed M, Masood N, Iman F, Azam H, Mozhgan Rezaei K, Habib G. Beneficial Effects of Melatonin and Atorvastatin on Retinopathy in Streptozocin-induced Diabetic Rats. Current Drug Therapy. 2019;14:1-8.

6. Dehdashtian E, Pourhanifeh MH, Hemati K, Mehrzadi S, Hosseinzadeh A. Therapeutic application of nutraceuticals in diabetic nephropathy: current evidence and future implications. Diabetes Metab Res Rev 2020.

7. Juybari KB, Hosseinzadeh A, Ghaznavi H, Kamali M, Sedaghat A, Mehrzadi S, Naseripour M. Melatonin as a modulator of degenerative and regenerative signaling pathways in injured retinal ganglion cells. Curr Pharm Design. 2019;25(28):3057-73.

8. Daryani A, Montazeri M, Pagheh AS, Sharif M, Sarvi S, Hosseinzadeh A, Reiter RJ, Hadighi R, Joghataei MT, Ghaznavi H. The potential use of melatonin to treat protozoan parasitic infections: a review. Biomed Pharmacother. 2018;97:948-57.

9. Mehrzadi S, Hemati K, Reiter RJ, Hosseinzadeh A. Mitochondrial dysfunction in age-related macular degeneration: melatonin as a potential treatment. Expert Opin Ther Targets. 2020;24(4):359-78.

10. Hemati K, Pourhanifeh MH, Dehdashtian E, Fatemi I, Mehrzadi S, Reiter RJ, Hosseinzadeh A. Melatonin and morphine: potential beneficial effects of co-use. Fund Clin Pharmacol 2020.

11. Cipolla-Neto J, Amaral FG, Afeche SC, Tan DX, Reiter RJ. Melatonin, energy metabolism, and obesity: a review. J Pineal Res. 2014;56(4):371-81.

12. Reiter RJ, Rosales-Corral SA, Tan DX, Acuna-Castroviejo D, Qin L, Yang SF, Xu K. Melatonin, a full service anti-cancer agent: inhibition of initiation, progression and metastasis. Int J Mol Sci. 2017;18(4):843.

13. Lu KH, Su SC, Lin CW, Hsieh YH, Lin YC, Chien MH, Reiter RJ, Yang SF. Melatonin attenuates osteosarcoma cell invasion by suppression of C-C motif chemokine ligand 24 through inhibition of the C-Jun N-terminal kinase pathway. J Pineal Res. 2018;65(3):e12507.

14. Ho HY, Lin CW, Chien MH, Reiter RJ, Su SC, Hsieh YH, Yang SF. Melatonin suppresses TPA-induced metastasis by downregulating matrix metalloproteinase-9 expression through JNK/SP-1 signaling in nasopharyngeal carcinoma. J Pineal Res. 2016;61(4):479-92.

15. Mediavilla MD, Guezmez A, Ramos S, Kothari L, Garijo F, Sanchez Barcelo EJ. Effects of melatonin on mammary gland lesions in transgenic mice overexpressing $\mathrm{N}$-ras proto-oncogene. J Pineal Res. 1997;22(2):86-94

16. Rao GN, Ney E, Herbert RA. Effect of melatonin and linolenic acid on mammary cancer in transgenic mice with c-neu breast cancer oncogene. Breast Cancer Res Treat. 2000;64(3):287-96.

17. Shi H, Chen Y, Tan DX, Reiter RJ, Chan Z, He C. Melatonin induces nitric oxide and the potential mechanisms relate to innate immunity against bacterial pathogen infection in Arabidopsis. J Pineal Res. 2015;59(1):102-8.

18. Wang J, Guo W, Chen W, Yu W, Tian Y, Fu L, Shi D, Tong B, Xiao X, Huang $W$, et al. Melatonin potentiates the antiproliferative and proapoptotic effects of ursolic acid in colon cancer cells by modulating multiple signaling pathways. J Pineal Res. 2013;54(4):406-16.

19. Shen YQ, Guerra-Librero A, Fernandez-Gil BI, Florido J, Garcia-Lopez S, Martinez-Ruiz L, Mendivil-Perez M, Soto-Mercado V, Acuna-Castroviejo $\mathrm{D}$, Ortega-Arellano $\mathrm{H}$, et al. Combination of melatonin and rapamycin for head and neck cancer therapy: suppression of AKT/mTOR pathway activation, and activation of mitophagy and apoptosis via mitochondrial function regulation. J Pineal Res. 2018;64(3):e12461.

20. Ball LJ, Palesh O, Kriegsfeld LJ. The pathophysiologic role of disrupted circadian and neuroendocrine rhythms in breast carcinogenesis. Endocr Rev. 2016;37(5):450-66.

21. Bojková B, Kubatka P, Qaradakhi T, Zulli A, Kajo K. Melatonin may increase anticancer potential of pleiotropic drugs. Int J Mol Sci. 2018;19(12):3910

22. Vijayalaxmi TCR Jr, Reiter RJ, Herman TS. Melatonin: from basic research to cancer treatment clinics. J Clin Oncol. 2002;20(10):2575-601.

23. Lee JH, Yun CW, Han YS, Kim S, Jeong D, Kwon HY, Kim H, Baek MJ, Lee SH. Melatonin and 5-fluorouracil co-suppress colon cancer stem cells by regulating cellular prion protein-Oct4 axis. J Pineal Res. 2018;65(4):e12519.

24. Lee H, Lee HJ, Jung JH, Shin EA, Kim SH. Melatonin disturbs SUMOylation-mediated crosstalk between c-Myc and nestin via MT1 activation and promotes the sensitivity of paclitaxel in brain cancer stem cells. J Pineal Res. 2018;65(2):e12496.

25. Su SC, Hsieh MJ, Yang WE, Chung WH, Reiter RJ, Yang SF. Cancer metastasis: mechanisms of inhibition by melatonin. J Pineal Res. 2017;62(1):e12370.

26. Bizzarri M, Proietti S, Cucina A, Reiter RJ. Molecular mechanisms of the pro-apoptotic actions of melatonin in cancer: a review. Expert Opin Ther Targets. 2013;17(12):1483-96.

27. Hosseinzadeh A, Kamrava SK, Joghataei MT, Darabi R, Shakeri-Zadeh A, Shahriari M, Reiter RJ, Ghaznavi H, Mehrzadi S. Apoptosis signaling pathways in osteoarthritis and possible protective role of melatonin. J Pineal Res. 2016;61(4):411-25

28. Zhang HM, Zhang Y. Melatonin: a well-documented antioxidant with conditional pro-oxidant actions. J Pineal Res. 2014;57(2):131-46.

29. Sainz R, Mayo J, Rodriguez C, Tan D, Lopez-Burillo S, Reiter RJ. Melatonin and cell death: differential actions on apoptosis in normal and cancer cells. Cell Mol Life Sci. 2003;60(7):1407-26.

30. Pourhanifeh MH, Hosseinzadeh A, Dehdashtian E, Hemati K, Mehrzad S. Melatonin: new insights on its therapeutic properties in diabetic complications. Diabetol Metab Syndr. 2020;12:1-20.

31. Leon-Blanco MM, Guerrero JM, Reiter RJ, Calvo JR, Pozo D. Melatonin inhibits telomerase activity in the MCF-7 tumor cell line both in vivo and in vitro. J Pineal Res. 2003;35(3):204-11.

32. Goradel NH, Asghari MH, Moloudizargari M, Negahdari B, HaghiAminjan $\mathrm{H}$, Abdollahi M. Melatonin as an angiogenesis inhibitor to combat cancer: Mechanistic evidence. Toxicol Appl Pharmcol. 2017;335:56-63.

33. Galluzzi L, Baehrecke EH, Ballabio A, Boya P, Bravo-San Pedro JM, Cecconi F, Choi AM, Chu CT, Codogno P, Colombo MI, et al. Molecular definitions of autophagy and related processes. EMBO J. 2017:36(13):1811-36.

34. Marinkovic M, Sprung M, Buljubasic M, Novak I. Autophagy modulation in cancer: current knowledge on action and therapy. Oxidative Med Cell Longev. 2018;2018:8023821

35. Hosseinzadeh A, Kamrava SK, Moore BC, Reiter RJ, Ghaznavi H, Kamali M, Mehrzadi S. Molecular aspects of melatonin treatment in tinnitus: a review. Curr Drug Targets. 2019;20(11):1112-28.

36. Kulikov AV, Luchkina EA, Gogvadze V, Zhivotovsky B. Mitophagy: Link to cancer development and therapy. Biochem Biophys Res Commun. 2017:482(3):432-9.

37. Porporato PE, Filigheddu N, Pedro JMB, Kroemer G, Galluzzi L. Mitochondrial metabolism and cancer. Cell Res. 2018;28(3):265-80.

38. Fernandez-Gil BI, Guerra-Librero A, Shen YQ, Florido J, Martinez-Ruiz L, Garcia-Lopez S, Adan C, Rodriguez-Santana C, Acuna-Castroviejo D, 
Quinones-Hinojosa A, et al. Melatonin enhances cisplatin and radiation cytotoxicity in head and neck squamous cell carcinoma by stimulating mitochondrial ROS generation, apoptosis, and autophagy. Oxidative Med Cell Longev. 2019;2019:7187128.

39. Liu R, Wang HL, Deng MJ, Wen XJ, Mo YY, Chen FM, Zou CL, Duan WF, Li $L$, Nie X. Melatonin inhibits reactive oxygen species-driven proliferation, epithelial-mesenchymal transition, and vasculogenic mimicry in oral cancer. Oxidative Med Cell Longev. 2018;2018:3510970.

40. Kim HS, Kim TJ, Yoo YM. Melatonin combined with endoplasmic reticulum stress induces cell death via the PI3K/Akt/mTOR pathway in B16F10 melanoma cells. PloS ONE. 2014;9(3):e92627.

41. Wang J, Xiao X, Zhang Y, Shi D, Chen W, Fu L, Liu L, Xie F, Kang T, Huang W, et al. Simultaneous modulation of COX-2, p300, Akt, and Apaf-1 signaling by melatonin to inhibit proliferation and induce apoptosis in breast cancer cells. J Pineal Res. 2012;53(1):77-90.

42. Chen L, Liu L, Li Y, Gao J. Melatonin increases human cervical cancer HeLa cells apoptosis induced by cisplatin via inhibition of JNK/Parkin/mitophagy axis in vitro cellular developmental biology. Animal. 2018;54(1):1-10

43. Maschio-Signorini LB, Gelaleti GB, Moschetta MG, Borin TF, JardimPerassi BV, Lopes JR, Lacerda JZ, Roela RA, Bordin NA, Correa LA, et al. Melatonin regulates angiogenic and inflammatory proteins in MDAMB-231 cell line and in co-culture with cancer-associated fibroblasts. Anti-cancer Agents Med Chem. 2016;16(11):1474-84.

44. Nopparat C, Chantadul V, Permpoonputtana K, Govitrapong P. The anti-inflammatory effect of melatonin in SH-SY5Y neuroblastoma cells exposed to sublethal dose of hydrogen peroxide. Mech Ageing Dev. 2017;164:49-60.

45. Zhang J, Xie T, Zhong X, Jiang HL, Li R, Wang BY, Huang XT, Cen BH, Yuan YW. Melatonin reverses nasopharyngeal carcinoma cisplatin chemoresistance by inhibiting the Wnt/ $\beta$-catenin signaling pathway. Aging. 2020;12(6):5423-38.

46. Akbarzadeh M, Movassaghpour AA, Ghanbari H, Kheirandish M, Fathi Maroufi N, Rahbarghazi R, Nouri M, Samadi N. The potential therapeutic effect of melatonin on human ovarian cancer by inhibition of invasion and migration of cancer stem cells. Sci Rep. 2017;7(1):17062.

47. Innominato PF, Lim AS, Palesh O, Clemons M, Trudeau M, Eisen A, Wang C, Kiss A, Pritchard Kl, Bjarnason GA. The effect of melatonin on sleep and quality of life in patients with advanced breast cancer. Supportive Care Cancer. 2016;24(3):1097-105.

48. Di Bella G, Mascia F, Ricchi A, Colori B. Evaluation of the safety and efficacy of the first-line treatment with somatostatin combined with melatonin, retinoids, vitamin D3, and low doses of cyclophosphamide in 20 cases of breast cancer: a preliminary report. Neuroendocrinol Lett. 2013;34(7):660-8

49. Wang $Y$, Wang $P$, Zheng $X$, Du $X$. Therapeutic strategies of melatonin in cancer patients: a systematic review and meta-analysis. OncoTargets Therapy. 2018;11:7895

50. Sigurdardottir LG, Valdimarsdottir UA, Fall K, Rider JR, Lockley SW, Schernhammer E, Mucci LA. Circadian disruption, sleep loss, and prostate cancer risk: a systematic review of epidemiologic studies. Cancer Epidemiol Prev Biomark. 2012;21(7):1002-11.

51. Sigurdardottir LG, Markt SC, Rider JR, Haneuse S, Fall K, Schernhammer ES, Tamimi RM, Flynn-Evans E, Batista JL, Launer L, et al. Urinary melatonin levels, sleep disruption, and risk of prostate cancer in elderly men. Eur Urol. 2015;67(2):191-4.

52. Bartsch C, Bartsch H, Schmidt A, Ilg S, Bichler K-H, Flüchter S-H. Melatonin and 6-sulfatoxymelatonin circadian rhythms in serum and urine of primary prostate cancer patients: Evidence for reduced pineal activity and relevance of urinary determinations. Clin Chim Acta. 1992;209(3):153-67.

53. Mayo JC, Hevia D, Quiros-Gonzalez I, Rodriguez-Garcia A, GonzalezMenendez P, Cepas V, Gonzalez-Pola I, Sainz RM. IGFBP3 and MAPK/ERK signaling mediates melatonin-induced antitumor activity in prostate cancer. J Pineal Res. 2017;62(1):e12373.

54. Joo SS, Yoo YM. Melatonin induces apoptotic death in LNCaP cells via p38 and JNK pathways: therapeutic implications for prostate cancer. J Pineal Res. 2009;47(1):8-14.

55. Tamarindo GH, Ribeiro DL, Gobbo MG, Guerra LHA, Rahal P, Taboga SR, Gadelha FR, Goes RM. Melatonin and docosahexaenoic acid decrease proliferation of PNT1A prostate benign cells via modulation of mitochondrial bioenergetics and ROS production. Oxidative Med Cell Longev. 2019;2019:5080798.

56. Jung-Hynes B, Schmit TL, Reagan-Shaw SR, Siddiqui IA, Mukhtar H, Ahmad N. Melatonin, a novel Sirt1 inhibitor, imparts antiproliferative effects against prostate cancer in vitro in culture and in vivo in TRAMP model. J Pineal Res. 2011;50(2):140-9.

57. Paroni R, Terraneo L, Bonomini F, Finati E, Virgili E, Bianciardi P, Favero G, Fraschini F, Reiter RJ, Rezzani R, et al. Antitumour activity of melatonin in a mouse model of human prostate cancer: relationship with hypoxia signalling. J Pineal Res. 2014;57(1):43-52.

58. Park JW, Hwang MS, Suh SI, Baek WK. Melatonin down-regulates HIF-1 alpha expression through inhibition of protein translation in prostate cancer cells. J Pineal Res. 2009;46(4):415-21.

59. Sohn EJ, Won G, Lee J, Lee S, Kim SH. Upregulation of miRNA3195 and miRNA374b mediates the anti-angiogenic properties of melatonin in hypoxic PC-3 prostate cancer cells. J Cancer. 2015;6(1):19-28.

60. Tai SY, Huang SP, Bao BY, Wu MT. Urinary melatonin-sulfate/cortisol ratio and the presence of prostate cancer: a case-control study. Sci Rep. 2016;6:29606.

61. Liu VWS, Yau WL, Tam CW, Yao KM, Shiu SYW. Melatonin inhibits androgen receptor splice variant-7 (AR-V7)-induced nuclear factor-kappa B (NF-kappaB) activation and NF-kappaB activator-induced AR-V7 expression in prostate cancer cells: potential implications for the use of melatonin in castration-resistant prostate cancer (CRPC) therapy. Int J Mol Sci. 2017;18(6):1130.

62. Rodriguez-Garcia A, Mayo JC, Hevia D, Quiros-Gonzalez I, Navarro M, Sainz RM. Phenotypic changes caused by melatonin increased sensitivity of prostate cancer cells to cytokine-induced apoptosis. J Pineal Res. 2013;54(1):33-45.

63. Terraneo L, Bianciardi P, Virgili E, Finati E, Samaja M, Paroni R. Transdermal administration of melatonin coupled to cryopass laser treatment as noninvasive therapy for prostate cancer. Drug Deliv. 2017;24(1):979-85.

64. Witjes JA. Bladder cancer in 2015: improving indication, technique and outcome of radical cystectomy. Nat Rev Urol. 2016;13(2):74-6.

65. Anghel RM, Gales LN, Trifanescu OG. Outcome of urinary bladder cancer after combined therapies. J Med Life. 2016;9(1):95-100.

66. Bellmunt J, Guix M. New agents for bladder cancer. Ann Oncol. 2010;21(Suppl 7):viii56-58.

67. Shrestha S, Zhu J, Wang Q, Du X, Liu F, Jiang J, Song J, Xing J, Sun D, Hou $Q$, et al. Melatonin potentiates the antitumor effect of curcumin by inhibiting IKKbeta/NF-kappaB/COX-2 signaling pathway. Int J Oncol. 2017:51(4):1249-60

68. Chen YT, Yang CC, Shao PL, Huang CR, Yip HK. Melatonin-mediated downregulation of ZNF746 suppresses bladder tumorigenesis mainly through inhibiting the AKT-MMP-9 signaling pathway. J Pineal Res. 2019;66(1):e12536.

69. Liu S, Liang B, Jia H, Jiao Y, Pang Z, Huang Y. Evaluation of cell death pathways initiated by antitumor drugs melatonin and valproic acid in bladder cancer cells. FEBS Open Bio. 2017;7(6):798-810.

70. Arabsalmani M, Mohammadian-Hafshejani A, Ghoncheh M, Hadadian F, Towhidi F, Vafaee K, Salehiniya H. Incidence and mortality of kidney cancers, and human development index in Asia; a matter of concern. J Nephropathol. 2017:6(1):30-42.

71. Society AC. Cancer prevention \& early detection facts \& figures, 2017-2018. In: Author Atlanta, GA; 2017.

72. Lin YW, Lee LM, Lee WJ, Chu CY, Tan P, Yang YC, Chen WY, Yang SF, Hsiao M, Chien MH. Melatonin inhibits MMP-9 transactivation and renal cell carcinoma metastasis by suppressing Akt-MAPKs pathway and NFkappaB DNA-binding activity. J Pineal Res. 2016;60(3):277-90.

73. Min KJ, Kim HS, Park EJ, Kwon TK. Melatonin enhances thapsigargininduced apoptosis through reactive oxygen species-mediated upregulation of CCAAT-enhancer-binding protein homologous protein in human renal cancer cells. J Pineal Res. 2012;53(1):99-106.

74. Um HJ, Park JW, Kwon TK. Melatonin sensitizes Caki renal cancer cells to kahweol-induced apoptosis through CHOP-mediated up-regulation of PUMA. J Pineal Res. 2011;50(4):359-66.

75. Park EJ, Woo SM, Min KJ, Kwon TK. Transcriptional and post-translational regulation of Bim controls apoptosis in melatonin-treated human renal cancer Caki cells. J Pineal Res. 2014;56(1):97-106. 
76. Calastretti A, Gatti G, Lucini V, Dugnani S, Canti G, Scaglione F, Bevilacqua A. Melatonin analogue antiproliferative and cytotoxic effects on human prostate cancer cells. Int J Mol Sci. 2018;19(5):1505.

77. Hevia D, Gonzalez-Menendez P, Fernandez-Fernandez M, Cueto S, Rodriguez-Gonzalez P, Garcia-Alonso Jl, Mayo JC, Sainz RM. Melatonin decreases glucose metabolism in prostate cancer cells: a (13)C stable isotope-resolved metabolomic study. Int J Mol Sci. 2017:18(8):1620.

78. Gobbo MG, Dizeyi N, Abrahamsson PA, Bertilsson PA, Masiteli VS, Pytlowanciv EZ, Taboga SR, Goes RM. Influence of melatonin on the proliferative and apoptotic responses of the prostate under normal and hyperglycemic conditions. J Diabetes Res. 2015;2015:538529.

79. Shiu SY, Leung WY, Tam CW, Liu VW, Yao KM. Melatonin MT1 receptorinduced transcriptional up-regulation of p27(Kip1) in prostate cancer antiproliferation is mediated via inhibition of constitutively active nuclear factor kappa B (NF-kappaB): potential implications on prostate cancer chemoprevention and therapy. J Pineal Res. 2013;54(1):69-79.

80. Kabasakal L, Sener G, Balkan J, Dogru-Abbasoglu S, Keyer-Uysal $\mathrm{M}$, Uysal M. Melatonin and beta-glucan alone or in combination inhibit the growth of dunning prostatic adenocarcinoma. Oncol Res. 2011;19(6):259-63.

81. Tam CW, Shiu SY. Functional interplay between melatonin receptormediated antiproliferative signaling and androgen receptor signaling in human prostate epithelial cells: potential implications for therapeutic strategies against prostate cancer. J Pineal Res. 2011;51(3):297-312.

82. Cho SY, Lee HJ, Jeong SJ, Lee HJ, Kim HS, Chen CY, Lee EO, Kim SH. Sphingosine kinase 1 pathway is involved in melatonin-induced HIF1 alpha inactivation in hypoxic PC-3 prostate cancer cells. J Pineal Res. 2011;51(1):87-93.

83. Jung-Hynes B, Huang W, Reiter RJ, Ahmad N. Melatonin resynchronizes dysregulated circadian rhythm circuitry in human prostate cancer cells. J Pineal Res. 2010;49(1):60-8.

84. Pirozhok I, Meye A, Hakenberg OW, Fuessel S, Wirth MP. Serotonin and melatonin do not play a prominent role in the growth of prostate cancer cell lines. Urol Int. 2010;84(4):452-60.

85. Tam CW, Chan KW, Liu VW, Pang B, Yao KM, Shiu SY. Melatonin as a negative mitogenic hormonal regulator of human prostate epithelial cell growth: potential mechanisms and clinical significance. J Pineal Res. 2008:45(4):403-12.

86. Tam CW, Mo CW, Yao KM, Shiu SY. Signaling mechanisms of melatonin in antiproliferation of hormone-refractory 22Rv1 human prostate cancer cells: implications for prostate cancer chemoprevention. J Pineal Res. 2007;42(2):191-202

87. Sainz RM, Mayo JC, Tan DX, Leon J, Manchester L, Reiter RJ. Melatonin reduces prostate cancer cell growth leading to neuroendocrine differentiation via a receptor and PKA independent mechanism. Prostate. 2005;63(1):29-43.

88. Shiu SY, Law IC, Lau KW, Tam PC, Yip AW, Ng WT. Melatonin slowed the early biochemical progression of hormone-refractory prostate cancer in a patient whose prostate tumor tissue expressed MT1 receptor subtype. J Pineal Res. 2003;35(3):177-82.

89. Siu SW, Lau KW, Tam PC, Shiu SY. Melatonin and prostate cancer cell proliferation: interplay with castration, epidermal growth factor, and androgen sensitivity. Prostate. 2002;52(2):106-22.
90. Rimler A, Lupowitz Z, Zisapel N. Differential regulation by melatonin of cell growth and androgen receptor binding to the androgen response element in prostate cancer cells. Neuroendocrinol Lett. 2002;23(Suppl 1):45-9.

91. Xi SC, Siu SW, Fong SW, Shiu SY. Inhibition of androgen-sensitive LNCaP prostate cancer growth in vivo by melatonin: association of antiproliferative action of the pineal hormone with $\mathrm{mt} 1$ receptor protein expression. Prostate. 2001;46(1):52-61.

92. Marelli MM, Limonta P, Maggi R, Motta M, Moretti RM. Growth-inhibitory activity of melatonin on human androgen-independent DU 145 prostate cancer cells. Prostate. 2000;45(3):238-44.

93. Xi SC, Tam PC, Brown GM, Pang SF, Shiu SY. Potential involvement of $\mathrm{mt} 1$ receptor and attenuated sex steroid-induced calcium influx in the direct anti-proliferative action of melatonin on androgen-responsive LNCaP human prostate cancer cells. J Pineal Res. 2000;29(3):172-83.

94. Moretti RM, Marelli MM, Maggi R, Dondi D, Motta M, Limonta P. Antiproliferative action of melatonin on human prostate cancer LNCaP cells. Oncol Rep. 2000;7(2):347-51.

95. Lissoni P, Cazzaniga M, Tancini G, Scardino E, Musci R, Barni S, Maffezzini M, Meroni T, Rocco F, Conti A, et al. Reversal of clinical resistance to $\mathrm{LHRH}$ analogue in metastatic prostate cancer by the pineal hormone melatonin: efficacy of LHRH analogue plus melatonin in patients progressing on LHRH analogue alone. Eur Urol. 1997;31(2):178-81.

96. Buzzell GR. Studies on the effects of the pineal hormone melatonin on an androgen-insensitive rat prostatic adenocarcinoma, the Dunning $R$ 3327 HIF tumor. J Neural Transm. 1988;72(2):131-40.

97. Xiao W, Xiong Z, Xiong W, Yuan C, Xiao H, Ruan H, Song Z, Wang C, Bao $L$, Cao Q, et al. Melatonin/PGC1A/UCP1 promotes tumor slimming and represses tumor progression by initiating autophagy and lipid browning. J Pineal Res. 2019;67(4):e12607.

98. Kim KJ, Choi JS, Kang I, Kim KW, Jeong CH, Jeong JW. Melatonin suppresses tumor progression by reducing angiogenesis stimulated by HIF-1 in a mouse tumor model. J Pineal Res. 2013;54(3):264-70.

99. Um HJ, Kwon TK. Protective effect of melatonin on oxaliplatin-induced apoptosis through sustained $\mathrm{Mcl}-1$ expression and anti-oxidant action in renal carcinoma Caki cells. J Pineal Res. 2010:49(3):283-90.

100. Lissoni P, Mandala M, Brivio F. Abrogation of the negative influence of opioids on IL-2 immunotherapy of renal cell cancer by melatonin. Eur Urol. 2000;38(1):115-8.

101. Lissoni P, Barni S, Tancini G, Ardizzoia A, Ricci G, Aldeghi R, Brivio F, Tisi E, Rovelli F, Rescaldani R, et al. A randomised study with subcutaneous low-dose interleukin 2 alone vs interleukin 2 plus the pineal neurohormone melatonin in advanced solid neoplasms other than renal cancer and melanoma. Br J Cancer. 1994;69(1):196-9.

102. Neri B, Fiorelli C, Moroni F, Nicita G, Paoletti MC, Ponchietti R, Raugei A, Santoni G, Trippitelli A, Grechi G. Modulation of human lymphoblastoid interferon activity by melatonin in metastatic renal cell carcinoma. A phase II study. Cancer. 1994;73(12):3015-9.

\section{Publisher's Note}

Springer Nature remains neutral with regard to jurisdictional claims in published maps and institutional affiliations.
Ready to submit your research? Choose BMC and benefit from:

- fast, convenient online submission

- thorough peer review by experienced researchers in your field

- rapid publication on acceptance

- support for research data, including large and complex data types

- gold Open Access which fosters wider collaboration and increased citations

- maximum visibility for your research: over $100 \mathrm{M}$ website views per year

At BMC, research is always in progress.

Learn more biomedcentral.com/submissions 